Psihologijske teme, 27 (2018), 3, 585-611

Pregledni rad - UDK - 159.942

616

159.938.363.6

doi:https://doi.org/10.31820/pt.27.3.12

\title{
Optimizam, pesimizam i tjelesno zdravlje
}

\author{
Igor Kardum, Jasna Hudek-Knežević i Nada Krapić \\ Sveučilište u Rijeci, Filozofski fakultet, Odsjek za psihologiju, Hrvatska
}

\begin{abstract}
Sažetak
U ovom su preglednom radu prikazani efekti optimizma i pesimizma na tjelesno zdravlje, kao i potencijalni mehanizmi kojim se ti efekti ostvaruju. U prvom je dijelu rada opisana konceptualna osnova optimizma i pesimizma, načini njihova mjerenja i osnovni problemi koji se pri tome javljaju. Nakon toga su navedeni najvažniji nalazi koji govore o efektima optimizma i pesimizma na mortalitet i druge specifične pokazatelje tjelesnog zdravlja. Detaljnije su prikazani odnosi optimizma i pesimizma s pokazateljima tjelesnoga zdravlja kod osoba zaraženih HIV-om i oboljelih od AIDSa. Opisano je nekoliko potencijalnih mehanizama kojima optimizam i pesimizam mogu djelovati na tjelesno zdravlje: kardiovaskularna reaktivnost, imunološke promjene, zdravstvena ponašanja, doživljaj stresa i suočavanje sa stresom. Na kraju su navedeni neki važni teorijski i metodološki problemi koje nalazimo u istraživanjima odnosa optimizma i pesimizma i tjelesnog zdravlja.
\end{abstract}

Ključne riječi: optimizam, pesimizam, tjelesno zdravlje, zdravstvena ponašanja

\section{Optimizam, pesimizam i njihovo mjerenje}

Optimizam se može konceptualizirati i mjeriti na različite načine, no najčešće se definira kao kognitivna pristranost, globalno očekivanje ili dispozicijski stav koji dovodi do precjenjivanja vjerojatnosti pozitivnih budućih događaja, odnosno do podcjenjivanja vjerojatnosti negativnih budućih događaja (Carver i Scheier, 2014; Peterson, 2000; Scheier i Carver, 1992). Suvremeni interes za optimizam ima dvojako ishodište. S jedne su strane to istraživanja unutar kognitivne psihologije šezdestih i sedamdesetih godina koja su pokazala da ljudsko procesiranje informacija nije ni točno ni realistično, tj. da ljudi pri tome čine brojne pogreške. Jedna je od takvih pogrešaka preferencija prema pozitivnijim informacijama. Matlin i Stang (1978) su, sumirajući rezultate velikog broja takvih istraživanja, pokazali da ljudi

Igor Kardum, Odsjek za psihologiju, Filozofski fakultet, Sveučilište u Rijeci, Sveučilišna avenija 4, 51000 Rijeka, Hrvatska. E-pošta: kardum@ffri.hr

Članak nastao u okviru znanstvenog projekta "Ličnost, emocije i socijalni procesi kao odrednice zdravstvenih ishoda" (13.04.1.2.01), koji financira Sveučilište u Rijeci. 
npr. upotrebljavaju više pozitivnih nego negativnih riječi, da se pri slobodnom dosjećanju brže dosjete pozitivnih nego negativnih događaja te da najveći broj ljudi sebe procjenjuje pozitivno, odnosno da se procjenjuju pozitivnije nego što procjenjuju druge osobe. Taylor i Brown (1988) također su, na osnovi pregleda literature, pokazali da su ljudi pristrani prema pozitivnijim informacijama te da su jedina iznimka od toga pravila pojedinci koji su anksiozni ili depresivni. Osim toga, pretpostavili su da je takva sveobuhvatna tendencija da se sebe vidi u najboljem mogućem svjetlu znak mentalnog zdravlja.

Drugo važno ishodište suvremenih poimanja optimizma jesu istraživanja optimizma kao relativno stabilne osobine ličnosti. Peterson (2000) ističe da su ove dvije tradicije $u$ shvaćanjima $i$ istraživanjima optimizma kompatibilne. Kognitivistička orijentacija usmjerena je na bazični optimizam, koji je sastavni dio ljudske prirode, a orijentacija na optimizam kao crtu ličnosti na činjenicu da naša iskustva utječu na to u kojoj ćemo mjeri biti optimistični ili pesimistični. U okviru je konceptualizacije optimizma kao osobine ličnosti najznačajnija ideja da su ponašanja ljudi pod velikim utjecajem njihovih očekivanja o posljedicama tih ponašanja. Iako je očekivanje ključan konstrukt u mnogim teorijama motivacije, kao što su Bandurina, Rotterova i Seligmanova, za suvremena shvaćanja optimizma kao osobine ličnosti najznačajnija su istraživanja Scheiera i Carvera (1992; Carver i Scheier, 2014). Naime, njihov interes za optimizam proizlazi iz istraživanja procesa koji se nalaze u osnovi samoregulacije ponašanja. Uloga optimizma u regulaciji vlastita ponašanja dolazi do izražaja onda kada pojedinac uoči razliku između ciljeva koje nastoji ostvariti i svoga trenutnog položaja u odnosu na te ciljeve. Optimisti, koje karakterizira očekivanje pozitivnih ishoda, ustrajat će u namjeri da smanje razliku koja ih dijeli do ostvarenja ciljeva, dok će pesimisti, koji očekuju loše ishode, u većoj mjeri pokazivati pasivne reakcije i odustajanje od ostvarenja postavljenih ciljeva. Dakle, oni pretpostavljaju da osobe koje poželjne ciljeve vide dostižnima ustraju u nastojanjima da ih ostvare, čak i onda kada je napredak težak i spor. Nasuprot tome, ako se ciljevi vide neostvarivima, ljudi odustaju od postavljenih ciljeva, čak i ako su ponekad posljedice odustajanja teške. Očekivanja nisu samo glavne determinante dviju širokih klasa ponašanja, kontinuiranog nastojanja za ostvarenjem ciljeva naspram odustajanja, nego i emocija (Carver i Scheier, 2014). Kada osoba vjeruje da su njezini ciljevi dostižni, prevladavaju pozitivne emocije, dok kod negativnih očekivanja prevladavaju negativne emocije. Iako očekivanja mogu biti specifična, tj. vezana uz neki pojedinačni cilj koji se želi ostvariti, Scheier i Carver (1992; Carver i Scheier, 2014) pretpostavljaju i postojanje globalnog očekivanja, koje je relativno stabilno kroz vrijeme i situacije, i koje zapravo predstavlja važnu karakteristiku ličnosti koju nazivaju dispozicionalnim optimizmom. Ovako konceptualizirani konstrukt optimizma vrlo je prikladan upravo za istraživanja zdravstvenih ishoda. Naime, optimizam se jasno uklapa u interakcijski stres-moderatorski model, uz naglasak na individualne razlike u sekundarnoj procjeni i naknadnim odgovorima suočavanja. 
Optimizam se najčešće mjeri LOT upitnikom (The Life Orientation Test; Scheier i Carver, 1985), koji se sastoji od osam čestica, četiri orijentiranih u smjeru optimizma i četiri u smjeru pesimizma, a konstruiran je s namjerom da posluži kao unidimenzionalna mjera dispozicijskog optimizma. $U$ originalnom su istraživanju ovih autora korištenjem eksploratorne faktorske analize izlučena dva međusobno povezana faktora $(r=.64)$, a rezultati su konfirmatorne faktorske analize upućivali na podjednaku pogodnost i jedno- $\mathrm{i}$ dvofaktorske solucije. Na temelju su tih rezultata autori odlučili upotrebljavati LOT kao jednodimenzionalnu mjeru, što je bio slučaj i s gotovo svim kasnijim istraživanjima u kojima je korišten ovaj upitnik. Međutim, nekoliko je kasnijih istraživanja pokazalo da bi optimizam i pesimizam trebalo shvatiti kao dvije zasebne dimenzije. Faktorske analize LOT upitnika često upućuju na njegovu dvodimenzionalnu strukturu (Glaesmer i sur., 2012), a istraživanja također pokazuju da su dimenzije optimizma i pesimizma različito povezane s mjerama mentalnog i tjelesnog zdravlja (Carver i Scheier, 2014). Dakle, iako optimizam i pesimizam mogu biti negativno povezani, istraživanja sve više upućuju na mogućnost da čestice LOT upitnika nisu bipolarni indikatori optimizma, nego da one reprezentiraju dva različita obilježja ličnosti, tj. optimizam i pesimizam. Posebno je mjerenje ovih dviju dimenzija pogotovo važno kod ispitivanja njihovih efekata u situacijski specifičnim kontekstima. Neka osoba npr. može biti vrlo optimistična u pogledu svoje karijere ili čak dispozicijski optimistična, ali istovremeno i vrlo pesimistična u pogledu svoga zdravlja. Na taj problem treba obratiti pozornost naročito pri ispitivanju zdravstvenih ishoda, posebno kod testiranja hipoteza koje proizlaze iz stres-moderatorskog modela odnosa između ličnosti i zdravlja, koji počiva na interakciji, odnosno transakciji karakteristika ličnosti i specifičnih situacija.

Razlikovanje ovih dviju dimenzija nije važno samo zbog njihova mjerenja, nego i zbog teorijskih razloga; ono omogućuje i ispitivanje potpuno novih problema, kao npr. ispitivanje razlika u efektima optimizma u odnosu na efekte niskog pesimizma (Mahler i sur., 2000; Serlachius i sur., 2015). Peterson (2000) npr. ističe potrebu za ispitivanjem osoba koje su istovremeno i pesimistične i optimistične, odnosno koje u budućnosti očekuju brojne i pozitivne i negativne ishode.

Uz navedeni problem treba napomenuti da se optimizam i pesimizam mogu konceptualizirati i kao relativno stabilne crte ličnosti, ali i kao stanja (Burke, Joyner, Cezch i Wilson, 2000). Istraživanja pokazuju da pozitivno i negativno raspoloženje mogu izazvati kratkotrajne promjene $u$ očekivanjima budućih pozitivnih i negativnih događaja (Morris, 1989) i da su vrijednosti koje ispitanici postižu na nekim mjerama optimizma i pesimizma pod utjecajem trenutnog raspoloženja ispitanika (Lewis i Dember, 1995). Osjetljivost upitnika optimizma i pesimizma na trenutno raspoloženje ispitanika može imati za posljedicu smanjenje vremenske stabilnosti ovih dimenzija, što onda znatno otežava i ispitivanje njihovih efekata na odložene ishode, kao što su npr. zdravstveni ishodi. LOT upitnik je, čini se, manje osjetljiv na trenutna emocionalna stanja ispitanika, pa se zbog toga može koristiti kada želimo 
mjeriti optimizam i pesimizam kao relativno stabilne crte ličnosti (Burke i sur., 2000). Međutim, Skala optimizma/pesimizma (OPS, Optimism/Pessimism Scale; Dember, Martin, Hummer, Howe i Melton, 1989) znatno je osjetljivija na trenutna raspoloženja ispitanika i čini se da ona više mjeri stanja optimizma i pesimizma. Ova skala mjeri individualne razlike u slaganju s principom Pollyanne, koji se manifestira u preferenciji prema pozitivnijim informacijama (Matlin i Stang, 1978) pri čemu se, za razliku od LOT-a, dimenzije optimizma i pesimizma boduju zasebno (Hummer, Dember, Melton i Schefft, 1992). Konstrukt sličan LOT-u mjeri i Skala beznadnosti (HS, Hopelessness Scale; Beck, Weissman, Lester i Trexler, 1974), no za razliku od LOT-a ova skala predstavlja širu mjeru konstrukta jer uz očekivanja mjeri i afektivne doživljaje kao i sklonosti prema odustajanju. Optimizam se može mjeriti i Skalom generaliziranog očekivanja uspjeha (Generalized Expectancy for Success Scale; Fibel i Hale, 1978), na kojoj ispitanici procjenjuju svoja specifična očekivanja kroz veći broj životnih situacija, te Testom tematske apercepcije (Strassle, McKee i Plant, 1999). Međutim, podaci o odnosima između ovih mjera još su uvijek nedostatni, tako da je i rezultate dobivene korištenjem različitih upitnika teško uspoređivati. Dosadašnja istraživanja čak govore o mogućnosti da navedeni upitnici mjere kvalitativno različite aspekte optimizma i pesimizma. Tako su npr. Burke i suradnici (2000) ispitujući konkuretnu valjanost LOT-a i OPS-a ustanovili da ova dva upitnika dijele vrlo mali postotak zajedničke varijance.

Problem vezan uz optimizam i pesimizam je i u tome što su njihove mjere, a pogotovo LOT upitnik, visoko zasićene neuroticizmom. Istraživanja pokazuju da statistička kontrola rezultata na neuroticizmu eliminira statistički značajne korelacije optimizma s tjelesnim simptomima i suočavajućim ponašanjima (Smith, Pope, Rhodewalt i Poulton, 1989). Ispitujući preklapanje neuroticizma i optimizma, Smith i suradnici (1989) izveli su konvergentno-diskriminativnu analizu valjanosti. U tri je nezavisna uzorka LOT bio visoko povezan s dvije mjere neuroticizma, a isti je slučaj i sa Skalom generaliziranog očekivanja uspjeha. Na osnovi toga autori zaključuju da se LOT može koristiti kao obrnuta mjera neuroticizma, odnosno da je taj upitnik u najmanju ruku snažno zasićen neuroticizmom. Mroczek, Spiro, Aldwin, Ozer i Bosse (1996) nalaze da se optimizam i pesimizam u velikoj mjeri preklapaju $\mathrm{s}$ ekstraverzijom i neuroticizmom, ali da stupanj preklapanja ovisi o ishodnim varijablama. Tako npr. kada je ishodna varijabla težina bolesti, tada ekstraverzija i neuroticizam u potpunosti mogu objasniti efekte pesimizma i optimizma, dok se kod nekih drugih ishodnih varijabli, kao što su svakodnevni stresni događaji i psihološki simptomi, kontroliranjem ekstraverzije i neuroticizma efekti optimizma i pesimizma smanjuju na pola. Navedeni rezultati govore da efekti optimizma i pesimizma na različite mjere zdravstvenih ishoda bar djelomično odražavaju efekte širih i temeljnijih dimenzija ličnosti, ekstraverzije i, pogotovo, neuroticizma. Između ostaloga, i zbog ovakvih je nalaza LOT upitnik revidiran i to tako da su iz njega maknute dvije čestice koje se odnose na suočavanje. Rezultati dobiveni korištenjem nove verzije LOT upitnika pokazuju da je optimizam povezan $s$ ishodnim varijablama čak i kada se statistički kontroliraju efekti neuroticizma, te da se latentna 
struktura upitnika sastoji od jednoga bipolarnog faktora (Scheier, Carver i Bridges, 1994).

\section{Optimizam, pesimizam i mortalitet}

Za sada postoji slaba evidencija o povezanosti optimizma i mortaliteta. U istraživanju Rottona (1992) optimizam mjeren kao smisao za humor nije bio povezan $\mathrm{s}$ mortalitetom, dok neka istraživanja govore da bi optimizam mogao biti povezan $\mathrm{s}$ višim mortalitetom (Friedman i sur., 1993; Tucker i Friedman, 1996). Ta istraživanja, temeljena na longitudinalnim podacima koje je 1921. godine počeo prikupljati Terman (Terman life-cycle study of children), pokazuju da djeca koju roditelji i nastavnici procjenjuju radosnom i sa smislom za humor imaju viši mortalitet izmjeren nakon više od 60 godina u odnosu na početno ispitivanje nego njihovi pesimističniji vršnjaci. Rizik povezan $\mathrm{s}$ tako mjerenim optimizmom sličan je tradicionalnim rizičnim faktorima za preranu smrtnost, kao što je npr. povišeni krvni tlak (Tucker i Friedman, 1996). Iako zdravstvena ponašanja objašnjavaju vrlo malo varijance mortaliteta, to je istraživanje pokazalo da optimističnija djeca u odrasloj dobi više puše i piju nego njihovi manje optimistični vršnjaci, dok brojni drugi ponašajni i psihosocijalni medijatori mjereni u odrasloj dobi (npr. socioekonomski status, bračni problemi, obrazovanje) uopće ne sudjeluju u objašnjenju povećanog rizika smrtnosti. Osim toga, moguće je da su razlozi zbog kojih optimistični pojedinci izvještavaju o manjem broju zdravstvenih simptoma i koji im omogućavaju brži oporavak nakon akutnih zdravstvenih problema istovremeno i razlozi koji dovode do povećanoga dugotrajnog rizika od negativnih zdravstvenih ishoda (npr. pušač može optimistično vjerovati da pušenje nema nikakvih štetnih zdravstvenih posljedica) (Tucker i Friedman, 1996). Autori navode i mogućnost da optimisti mogu biti naročito ugroženi kada stvari krenu loše, pa rezultirajući stres i lošije zdravstvene navike mogu imati pojačane negativne efekte. To može biti posljedica nerealističnog optimizma, ali i fizioloških i imunoloških promjena koje nastaju uslijed većeg ulaganja napora optimista tijekom stresa (Nes, Segerstrom i Sephton, 2005; Segerstrom, 2005). Dakle, iako su optimizam i humor često povezani s boljim zdravstvenim ishodima, to je najvjerojatnije zbog toga što funkcioniraju kao adaptivni mehanizmi suočavanja u specifičnim stresnim situacijama, ali ne i kao globalni prediktori zdravlja i dužine života (Friedman i sur., 1993). Treba svakako dodati da se rezultati ovoga istraživanja uglavnom ne slažu s rezultatima sličnih istraživanja. Npr. Danner, Snowdon i Friesen (2001) su na uzorku redovnica našle vrlo visoku povezanost između pozitivnog emocionalnog sadržaja u autobiografijama koje su napisane u dobi od 18. do 32. godine i dužine života izmjerenog šest desetljeća kasnije. Koristeći istu populaciju kao i Friedman i suradnici, ali ponešto drugačije izvore podataka, i polazeći od optimizmu srodnog konstrukta eksplanatornog stila kao prediktorske varijable, Peterson, Seligman, Yurko, Martin i Friedman (1998) dobivaju pozitivnu povezanost između pesimističkog eksplanatornog stila i mortaliteta. Naravno, razlike u dobivenim 
rezultatima u odnosu na istraživanje Friedmana i suradnika (1993) mogu biti posljedica i kvalitativnih razlika između različitih mjera optimizma. Analize preživljavanja provedene na osobama oboljelim od AIDS-a (Reed, Kemeny, Taylor, Wang i Visscher, 1994) i karcinoma (Schulz, Bookwala, Knapp, Scheier i Williamson, 1996) također govore o optimizmu kao faktoru koji je povezan s dužim preživljavanjem i o pesimizmu kao faktoru kraćeg preživljavanja. Posebno je zanimljivo istraživanje Schulza i suradnika (1996), koji su se kao prediktorima preživljavanja koristili zasebnim mjerama optimizma i pesimizma. Njihovi su rezultati pokazali da samo pesimizam značajno predviđa mortalitet izmjeren osam mjeseci kasnije, te da je on, čak i uz kontrolu efekata depresivnosti, značajan rizični faktor mortaliteta posebno kod mlađih bolesnika (u dobi od 30 do 59 godina). Iako specifični mehanizmi djelovanja pesimizma na mortalitet nisu ispitivani, autori pretpostavljaju da on djeluje na ponašanja, kao što je npr. provođenje propisanog medicinskog tretmana i/ili direktno na endokrini i imunološki sustav. Dakle, uz jednu iznimku, istraživanja, uključujući i metaanalitička (Chida i Steptoe, 2008; Rasmussen, Scheier i Greenhouse, 2009), uglavnom pokazuju da je optimizam povezan $\mathrm{s}$ dužim preživljavanjem i kod zdravih i kod bolesnih ispitanika, a pesimizam s kraćim.

\section{Optimizam, pesimizam i ostali zdravstveni ishodi}

Istraživanja pokazuju da su optimizam i pesimizam povezani s velikim brojem različitih zdravstvenih ishoda i da ta povezanost vrijedi za cijeli svijet, a ne samo za industrijalizirane zapadne zemlje (Gallagher, Lopez i Pressman, 2013). Metaanalitička istraživanja (npr. Andersson, 1996; Rasmussen i sur., 2009) pokazuju da je optimizam mjeren LOT upitnikom najpouzdanije povezan s mjerama suočavanja sa stresom, negativnim afektom i subjektivnim tjelesnim simptomima. Već su prilikom konstrukcije LOT-a Scheier i Carver (1985) našli da je kod studenata u vrijeme ispitnog perioda optimizam značajan negativan prospektivni prediktor subjektivnih tjelesnih simptoma, čak i nakon statističke kontrole početne razine simptoma. Međutim, iako je veza između optimizma i subjektivnih tjelesnih simptoma više puta replicirana (Carver i Scheier, 2014), iz ove povezanosti nije jasno je li zdravstveno stanje optimista zaista bolje ili oni samo optimistično izvještavaju o svojem zdravstvenom statusu. Zbog toga su za procjenu povezanosti optimizma i pesimizma sa zdravstvenim ishodima značajnija ona istraživanja koja uključuju i objektivne indikatore zdravstvenog statusa. Jedno su od prvih takvih istraživanja izveli Scheier i suradnici (1989) na grupi muških ispitanika koji su podvrgnuti kirurškoj intervenciji ugradnje premosnica na koronarnim arterijama. Rezultati su tog istraživanja pokazali da dispozicijski optimizam ima pozitivne efekte na cijeli niz indikatora zdravstvenog stanja i brzine oporavka. Optimisti, za razliku od pesimista, pokazuju značajno manje fizioloških znakova koji upućuju na infarkt miokarda tijekom operacije, a također pokazuju i značajno više znakova tjelesnog oporavka tjedan dana nakon operacije. Liječničke procjene govore da se optimisti značajno 
brže oporavljaju, a osim toga optimisti se značajno brže vraćaju različitim životnim aktivnostima nego pesimisti. Pet godina nakon operacije optimisti, češće nego pesimisti, rade puno radno vrijeme, a ako se kod pacijenata javila angina pektoris, tada je bol koju doživljavaju optimisti značajno manja od one koju doživljavaju pesimisti (Scheier i Carver, 1992). Mahler i suradnici (2000) ispitivali su zasebne efekte optimizma i pesimizma izmjerene nakon operacije ugradnje premosnica na koronarnim arterijama na mjere tjelesnog (bol i funkcionalni status) i psihološkog (pozitivni i negativni afekt) stanja, koje su prikupljene u pet navrata tijekom godine dana nakon operacije. Njihovi su rezultati pokazali da se na osnovi pesimizma bolje može predvidjeti funkcionalni i psihološki status pacijenata nakon otpuštanja iz bolnice. Dakle, niži pesimizam, a ne viši optimizam, povezan je s boljim stanjem pacijenata. Također, ovo je istraživanje pokazalo da prediktivna vrijednost optimizma i pesimizma ovisi i o vremenu proteklom od operacije do mjerenja ishodnih varijabli. Optimizam je više povezan sa smanjenom boli neposredno nakon otpuštanja iz bolnice, dok je niski pesimizam povezan sa smanjenjem boli tijekom kasnijih mjerenja. Ovi rezultati govore u prilog pretpostavci da su optimizam i pesimizam dva različita konstrukta koja nisu funkcionalno ekvivalentna. Veći broj drugih istraživanja također pokazuje da se optimisti brže bolnički oporavljaju i bolje prilagođavaju nakon kirurških intervencija i rehabilitacije (Ben-Zur, Rappaport, Ammar i Uretzky, 2000; DuBois i sur., 2015; Hevey, McGee i Horgan, 2014) te da nakon kirurške intervencije imaju smanjenu vjerojatnost ponovne hospitalizacije (Scheier i sur., 1999).

Istraživanja su također pokazala da su optimizam i pesimizam povezani i $\mathrm{s}$ drugim objektivnim i prospektivno mjerenim indikatorima zdravstvenog statusa. Pesimistične žene npr. imaju veći broj atipičnih izraslina u cerviksu (Antoni i Goodkin, 1988), dok optimisti imaju duže telomere (Schutte, Palanisamy i McFarlane, 2016), što ih čini otpornijim na oboljevanje i mortalitet. Optimizam također ima pozitivnu ulogu pri trudnoći i porodu, pa npr. optimističnije majke rađaju težu djecu čak i nakon statističke kontrole brojnih faktora koji mogu utjecati na težinu novorođenčadi, kao što su razina doživljenog stresa, dužina gestacije, bračni status, dob majke, prihodi, obrazovanje, etnička pripadnost i paritet (Rini, Dunkel-Schetter, Wadhawa i Sandman, 1999). Istraživanje koje su proveli Lobel, DeVincent, Kaminer i Meyer (2000) na majkama s rizičnom trudnoćom pokazuje da je niski optimizam povezan $\mathrm{s}$ nižom težinom novorođenčadi. Iako su manje optimistične žene doživljavale više stresa tokom cijele trudnoće, on nije imao utjecaj na ishod trudnoće, a čini se da su pozitivni efekti optimizma posredovani ponašajnim mehanizmom, tj. češćim vježbanjem koje je utvrđeno kod optimističnijih žena. Općenito, čini se da optimizam ima pozitivne učinke na cijeli niz zdravstvenih ishoda, s veličinom efekta koji se kreću od malih do umjerenih (Rasmussen i sur., 2009).

Zbog očiglednih pozitivnih efekata optimizma na zdravstvene ishode, posebno na prilagodbu kroničnim bolestima, Taylor (1983) je optimizam uključila u svoju teoriju kognitivne adaptacije. Njezina teorija pretpostavlja da se uspješna prilagodba 
na kronične bolesti ostvaruje putem nekoliko pozitivnih kognitivnih pristranosti. Oni pojedinci koji suočeni s kroničnom bolešću mogu održati ili razviti optimističniji pogled na budući tijek bolesti, koji nastoje uspostaviti kontrolu nad svojom bolešću i koji mogu obnoviti svoje samopoštovanje kroz proces socijalne usporedbe na niže, bolje se prilagođavaju na novonastalo stanje, što dovodi do njihova boljega psihološkog i tjelesnog statusa. To su pokazala istraživanja na oboljelima od različitih vrsta karcinoma (Hodges i Winstanley, 2012), ženama s karcinomom dojke (Epping-Jordan i sur., 1999), zatim na majkama djece s perinatalnim problemima (Afflek, Tennen i Gershman, 1985), na pacijentima s AIDS-om (Taylor, Kemeny, Bower, Gruenewald i Reed, 2000) i na pacijentima sa srčanim oboljenjima (Helgeson i Fritz, 1999; Hevey, McGee i Horgan, 2014). Tako npr. Helgeson i Fritz (1999) na pacijentima koji su podvrgnuti kirurškoj intervenciji proširenja srčanih arterija nalaze da oni ispitanici koji pokazuju veću percepciju kontrole nad svojom bolešću, pozitivna očekivanja u budućnosti i pozitivan pogled na sebe imaju tijekom sljedećih šest mjeseci manji rizik od nove kardiološke disfunkcije, čak i nakon statističke kontrole demografskih i medicinskih varijabli. Iako njihovo istraživanje nije uspjelo identificirati i mehanizme kojim opisane kognitivne pristranosti ostvaruju svoj pozitivan učinak, autori pretpostavljaju da oni vjerojatno djeluju tako što smanjuju fiziološku reaktivnost na stresore omogućavajući manju izloženost stresorima ili smanjujući vjerojatnost interpretiranja događaja kao stresnih.

Međutim, usprkos svim navedenim rezultatima za sada se ne može reći da postoji čvrsta veza između optimizma, pesimizma i tjelesnog zdravlja. Naime, još uvijek nedostaju empirijski nalazi koji bi govorili o mogućnosti predviđanja incidencije pojedinih bolesti na osnovi optimizma i pesimizma, a relativno su slabo istraženi i mehanizmi koji povezuju ove dvije dimenzije i zdravlje. Osim toga, postoje i rezultati istraživanja koji su negativni. Tako npr. Bleiker, van der Ploeg, Ader i Hendriks (1996) ne nalaze povezanost između optimizma i razvoja karcinoma dojke, Lyons i Chamberlain (1994) navode da su infekcije gornjih dišnih puteva pod utjecajem svakodnevnih stresnih događaja češće kod optimista nego pesimista, a također postoji i evidencija da je optimizam povezan sa smanjenom imunokompetencijom (Carver i Scheier, 2014) i supkliničkom aterosklerozom (Ferrer i sur., 2012).

\section{Optimizam, pesimizam, HIV i AIDS}

Velik je broj istraživanja o efektima optimizma, ali i drugih karakteristika ličnosti na zdravstvene ishode proveden na ispitanicima koji su zaraženi HIV-om ili koji boluju od AIDS-a. Ti su se ispitanici zbog više razloga pokazali vrlo prikladnim za razumijevanje utjecaja psihosocijalnih varijabli na tijek bolesti (Ammirati, Lamis, Campos i Farber, 2015; Taylor i sur., 2000). Prvo, u SAD-u, gdje je i provedena većina takvih ispitivanja, postoji vrlo velik broj inficiranih pojedinaca koji su identificirani u ranoj, asimptomatskoj fazi bolesti, tako da je moguće pratiti tijek 
bolesti od samoga početka. Kod mnogih drugih bolesti, kao što su rak ili kardiovaskularne bolesti, najčešće nije moguće identificirati bolesnike u asimptomatskoj fazi, nego se mora čekati dok bolest ne postane manifestna. Drugo, populacija s HIV-om mlađa je nego što je to slučaj s drugim kroničnim bolestima, tako da se mogu izbjeći mnoge poteškoće koje se javljaju pri ispitivanju odnosa između psihosocijalnih faktora i zdravstvenih ishoda kod starije populacije. Jedan je od tih problema utjecaj jedne kronične bolesti na drugu, a koji se kod HIV-a ne javlja sve do kasne faze bolesti. Treće, za razliku od ostalih kroničnih bolesti kod HIV infekcija bolje su poznati faktori koji mogu utjecati na odnos između psihosocijalnih varijabli i tijeka bolesti (npr. dob, korištenje alkohola i droga, uzimanje lijekova, itd), pri čemu se oni mogu pouzdano mjeriti i statistički kontrolirati. Četvrto, budući da se bolest može pratiti tijekom dugog vremena, od asimptomatske faze do smrti, to nam omogućava ispitivanje različitih putova kroz koje se manifestira efekt psihosocijalnih varijabli, kao što su npr. promjene u emocionalnim stanjima ispitanika, promjene u socijalnoj podršci, zdravstvene navike, izlaganje stresorima itd. Peto, za razliku od mnogih drugih kroničnih bolesti kod HIV infekcije napredak bolesti može se izraziti na ordinalnoj skali (npr. brojem CD4 T-limfocita), što nam npr. omogućava ispitivanje odnosa između psihosocijalnih varijabli i tijeka bolesti kroz različite faze bolesti. Šesta prednost HIV-a kao bolesti prikladne za ispitivanje odnosa između psihosocijalnih varijabli i zdravstvenih ishoda je u tome što se uz infekciju HIV-a vežu jasni klinički znakovi, kao što su pojava simptoma, zatim dijagnoza AIDS-a i smrt.

U jednom su od prvih takvih istraživanja Taylor i suradnici (1992) našli da su muški homoseksualci koji su HIV seropozitivni i koji su nerealno optimistični u pogledu budućeg tijeka svoje infekcije bolje prilagođeni te da se aktivnije suočavaju nego manje optimistični ispitanici. Osim toga, pokazalo se da nerealistični optimizam ne utječe na njihova zdravstvena ponašanja ni na rizična seksualna ponašanja. Reed i suradnici (1994) su na uzorku muških homoseksualaca s dijagnozom AIDS-a ispitivali suočavanje $\mathrm{s}$ tom bolešću, odnosno s njezinim utjecajem na njihovo zdravlje te s njezinom smrtonosnom prirodom. Faktorskom su analizom odgovora suočavanja između ostalih izdvojili i faktor koji su nazvali realistično prihvaćanje (primjer čestice - "Pripremam se na najgore."). Bolesnici koji imaju visoke rezultate na tom faktoru prihvaćaju mogućnost skoroga smrtnog ishoda, dok se oni s niskim rezultatom ni mentalno ni ponašajno ne opterećuju tom mogućnošću. Autori su izveli analizu preživljavanja kod ispitanika s visokim i niskim rezultatom na tom faktoru i našli su da bolesnici koji na njemu imaju visok rezultat umiru u prosjeku devet mjeseci ranije nego bolesnici s niskim rezultatom, čak i nakon statističke kontrole brojnih varijabli koje se mogu smatrati potencijalnim prediktorima smrtnosti, kao što su dob, broj simptoma AIDS-a, razina CD4 Tpomoćničkih stanica itd. Dakle, nerealistični optimizam prospektivno je povezan $\mathrm{s}$ nešto dužim preživljavanjem. Zanimljivo je da ni jedan mehanizam odnosa između psihosocijalnih varijabli i tijeka bolesti koji su ovi autori ispitivali (zdravstvena ponašanja, socijalna podrška, briga o vlastitu zdravlju, emocionalna stanja) ne može 
objasniti vezu između realističnog prihvaćanja i bržeg umiranja. Autore je zanimalo vrijedi li taj odnos i u drugim fazama bolesti, pa su na uzorku muškaraca inficiranih HIV-om, ali bez simptoma bolesti ispitali vezu između specifičnih negativnih očekivanja vezanih uz AIDS i pojave simptoma AIDS-a (Reed, Kemeny, Taylor i Visscher, 1999). Dobiveni su rezultati pokazali da su negativna očekivanja specifično vezana uz AIDS značajan prediktor pojave simptoma AIDS-a kod prethodno asimptomatskih seropozitivnih muškaraca te da je to naročito izraženo kod onih ispitanika koji su u stanju žalovanja zbog toga što im je bliski prijatelj ili partner umro od AIDS-a. Oko dvije trećine ispitanika u fazi žalovanja razvija simptome AIDS-a u usporedbi s 40 do $50 \%$ ispitanika u drugim grupama, čak i uz statističku kontrolu imunoloških parametara, lijekova, depresivnosti i rizičnog seksualnog ponašanja. Dakle, ovo istraživanje pokazuje da su specifična negativna očekivanja značajan psihosocijalni prediktor bržeg napredovanja bolesti kod prethodno asimptomatskih ispitanika, pri čemu je njihov efekt pojačan ako su ispitanici u stanju žalovanja koje je također specifično povezano uz AIDS.

Sumirajući, možemo reći da prethodno navedena istraživanja pokazuju da, barem kada se radi o ispitanicima s HIV-om odnosno s AIDS-om, optimistična, čak i nerealno optimistična očekivanja jesu važan resurs koji ljudima pomaže u intenzivno stresnim i životno prijetećim situacijama. Međutim, za sada još uvijek ne znamo mehanizme kojima to pozitivno psihološko stanje ostvaruje svoje zaštitne efekte na tjelesno zdravlje. Neki su od potencijalnih mehanizama testirani u ovim istraživanjima, međutim, ni jedan od njih ne objašnjava vezu između optimističnih očekivanja i pozitivnijih zdravstvenih ishoda. Zbog toga Taylor i suradnici (2000) pretpostavljaju da kognitivne varijable, $u$ koje po njihovom mišljenju pripada $\mathrm{i}$ optimistično očekivanje, imaju zaseban značaj za zdravstvene ishode, odnosno da kognicije mogu imati alternativan put do biologije bolesti, barem kada se radi o infekcijama HIV-om i AIDS-u. Treba napomenuti da iako suvremeni pristupi najčešće optimizam smatraju kognitivnim obilježjem, on ipak nije samo kognicija, nego uključuje i važne emocionalne i motivacijske komponente (Peterson, 2000). Zbog toga bi detaljnije trebalo ispitati mehanizme koji su u vezi s tim komponentama optimizma, pri čemu jedan od potencijalno važnih mehanizama čine pozitivne emocije povezane i s optimizmom (Carver i Scheier, 2014) i s imunološkim promjenama (Salovey, Detweiler, Steward i Rothman, 2000).

\section{Mehanizmi povezanosti optimizma i pesimizma sa zdravstvenim ishodima}

\section{Optimizam, pesimizam i kardiovaskularno funkcioniranje}

Nalazi da optimisti pokazuju manje znakova intraoperativnih komplikacija, brži oporavak nakon operacije ugradnje srčanih premosnica te manje hostilnosti i depresivnosti neposredno prije operacije naveli su Scheiera i Carvera (1987) na 
zaključak da je kardiovaskularna reaktivnost na stres jedan od fizioloških mehanizama koji se nalazi u osnovi povezanosti optimizma i zdravstvenih ishoda. To potvrđuju i neka eksperimentalna istraživanja (npr. Williams, Riels i Roper, 1990) koja pokazuju da je oporavak i sistoličkog i dijastoličkog krvnog tlaka nakon stresnog zadatka brži kod optimista nego kod pesimista te da pesimisti pri susretu sa stresnim zadatkom pokazuju veću kardiovaskularnu reaktivnost mjerenu dijastoličkim krvnim tlakom. Ovu pretpostavku indirektno potvrđuju i rezultati istraživanja koji govore da osobe koje se u stresnoj situaciji koriste humorom pokazuju smanjenu psihofiziološku reaktivnost mjerenu pulsom, električnom provodljivošću i temperaturom kože (Newman i Stone, 1996). U skladu sa Scheierom i Carverom (1987) razlike u krvnom tlaku i pulsu pokazuju da pesimisti reagiraju na stres većom kardiovaskularnom reaktivnošću nego optimisti te da je optimizam/pesimizam faktor koji je odgovoran za negativne zdravstvene posljedice hostilnosti. Tome u prilog idu krossekcijski i prospektivni rezultati njihovih istraživanja, koji pokazuju da povezanost između optimizma i tjelesnih simptoma ostaje značajna i nakon statističke kontrole hostilnosti, dok veza između hostilnosti i tjelesnih simptoma nakon kontrole efekata optimizma više nije statistički značajna. Williams i suradnici (1990) pretpostavljaju da jedan od mehanizam koji se nalazi u osnovi veze između pesimizma i zdravstvenih ishoda uključuje povećanu pozornost pesimista. Naime, hiperpozornost nalazimo i kod hostilnih osoba, a ona dovodi do učestalijeg i intenzivnijeg pretraživanja okoline, što, pak, izaziva povišenu kardiovaskularnu reaktivnost na stres. U skladu su s tom pretpostavkom i rezultati njihova istraživanja koji pokazuju da pesimisti, u odnosu na optimiste, pokazuju višu razinu anksioznosti i veći umor nakon stresnog zadatka, što su, po njihovu mišljenju, upravo posljedice kronično povećane razine pozornosti (Williams i sur., 1990). Kod ispitanika koji su podvrgnuti ugradnji premosnica na srčanim arterijama Scheier i suradnici (1989) nalaze efekte optimizma na intraoperativne komplikacije, liječničke procjene tjelesnog oporavka i normalizaciju aktivnosti koji nisu posredovani strategijama suočavanja. Dakle, iako se ovim problemom bavilo vrlo malo istraživanja, dosadašnji nalazi govore u prilog mogućnosti da pesimizam može djelovati na pojavu kardiovaskularnih oboljenja, i to u onoj mjeri u kojoj pesimisti pokazuju veću kardiovaskularnu reaktivnost na stresne događaje.

\section{Optimizam, pesimizam i imunološke promjene}

Za sada postoji malo istraživanja koja su se bavila efektima optimizma i pesimizma na imunološke promjene, a i rezultati tih istraživanja nisu uvijek jednoznačni. Istraživanja izvršena na ispitanicima zaraženih HIV-om najčešće pokazuju da je optimizam i kod muškaraca i kod žena povezan s boljim, a pesimizam s lošijim imunološkim funkcioniranjem (Byrnes i sur., 1998; Taylor i sur., 2000). U istraživanju Cruessa i suradnika (2000) ispitivan je efekt dispozicijskog optimizma na psihološki i imunološki status muškaraca inficiranih HIV-om nakon doživljenog stresnog događaja (razornog uragana). Rezultati su tog istraživanja pokazali da je i 
nekoliko mjeseci nakon stresnog događaja optimizam povezan s nižom razinom depresivnosti i doživljenog stresa te $\mathrm{s}$ boljim staničnim imunološkim funkcioniranjem. Pri tome su efekti optimizma djelomično posredovani depresivnošću samo kod protutijela za Epstein-Barrov virus, dok njegovi efekti na ostale imunološke parametre nisu posredovani psihološkim stanjima ispitanika. Međutim, u nekim istraživanjima izvedenim na sličnim uzorcima ispitanika nije dobiven efekt optimizma na imunološke promjene. Kontrolirajući efekte dobi, obrazovanja, zaposlenja, trajanja infekcije i korištenja lijekova, Tomakovsky, Lumley, Markowitz i Frank (2001) nalaze da optimizam ni trenutno ni nakon dvije godine nije povezan s brojem CD4 stanica.

Istraživanja izvedena na zdravim ispitanicima također uglavnom govore o pozitivnim učincima optimizma. Sieber i suradnici (1992) su ispitujući efekte kontrolabilnih i nekotrolabilnih stresnih događaja na neposredne i odložene imunološke odgovore našli smanjenu aktivnost NK stanica kod ispitanika koji smatraju da nemaju kontrolu nad stresnim događajem. Međutim, rezultati su tog istraživanja pokazali da optimizam smanjuje i neposredne i odložene negativne efekte nekontrolabilnih stresnih događaja na aktivnost NK stanica. Slične su rezultate dobili Segerstrom, Taylor, Kemeny i Fahey (1998), u čijem je istraživanju optimizam također bio povezan $\mathrm{s}$ većom aktivnošću NK stanica, ali i $\mathrm{s}$ većim brojem pomoćničkih T-stanica. Pri tome je efekt optimizma na aktivnost NK stanica djelomično posredovan intenzitetom stresa, a na broj pomoćničkih T-stanica raspoloženjem. Ispitivanje učinka optimizma i pesimizma na imunološke promjene u uvjetima akutnih i kroničnih stresora i životnih promjena pokazuje da ove dvije dimenzije mogu imati različite imunološke efekte te da oni ovise o vrsti stresora (Cohen i sur., 1999). Naime, optimisti pokazuju bolje imunološko funkcioniranje nakon djelovanja akutnih stresora, međutim, kod dugotrajnijih i intenzivnijih stresnih događaja optimisti pokazuju lošije imunološko funkcioniranje nego pesimisti. Općenito, čini se da je kod složenijih, dugotrajnijih i nekontrolabilnijih stresnih događaja optimizam negativno povezan s mjerama stanične imunosti, a kada se radi o jednostavnijim, kraćim i kontrolabilnijim događajima, tada je ta povezanost pozitivna (Segerstrom, 2005). Iako se negativna povezanost optimizma i imunoloških parametara ponekad objašnjava razočaranjem zbog neostvarenja njihovih pozitivnih očekivanja, dosadašnji rezultati više govore u prilog hipotezi o narušavanju imunološkog statusa zbog povećanog angažmana optimista tijekom izlaganja ozbiljnijim stresnim događajima (Segerstrom, 2006).

Iako su nužna dodatna istraživanja kojima bi se preciznije odredili potencijalno različiti utjecaji optimizma i pesimizma na imunološke promjene, navedena istraživanja svakako pokazuju da su efekti ovih dviju dimenzija na imunološko funkcioniranje jedan od potencijalnih mehanizama kojim one mogu biti povezane sa zdravstvenim ishodima. 


\section{Optimizam, pesimizam i zdravstvena ponašanja}

Jedan su od najvjerojatnijih mehanizama djelovanja optimizma i pesimizma na zdravstvene ishode zdravstvena ponašanja. Naime, brojna su istraživanja pokazala da optimisti manifestiraju pozitivnija zdravstvena ponašanja nego pesimisti. U istraživanju koje je uključivalo petogodišnje praćenje bolesnika kojima je izvršena operacija ugradnje premosnica na srčanim arterijama (Scheier i sur., 1989) ispitivane su i zdravstvene navike pacijenata. Tijekom tog perioda optimisti češće nego pesimisti stječu naviku redovitog uzimanja vitamina, manje jedu nezdravu hranu i češće se uključuju u kardiološke rehabilitacijske programe (Scheier i Carver, 1992). Shepperd, Maroto i Pbert (1996) su na uzorku pacijenata koji su tijekom 18 tjedana pohađali kardiološki rehabilitacijski program ispitivali efekte optimizma na osam koronarnih rizičnih faktora. Njihovi su rezultati pokazali da su na kraju programa optimisti značajno više nego pesimisti smanjili uzimanje hrane koja sadrži masnoću, značajno su smanjili tjelesnu masnoću i opći koronarni rizik, te značajno povećali svoj aerobni kapacitet. Dakle, optimizam može predviđati uspješnost promjena zdravstvenih ponašanja, a ovo istraživanje pokazuje da je to moguće čak i nakon kontrole efekata uobičajenih prediktora promjena zdravstvenih ponašanja kao što su dob, spol i veličina postavljenog cilja. Metaanalitičko istraživanje (Boehm i sur., 2018) također pokazuje da optimistične osobe imaju smanjeni rizik za oboljevanje i mortalitet od kardiovaskularnih bolesti jer su češće tjelesno aktivne, jedu više voća i povrća i manje puše.

Slični su efekti optimizma dobiveni i kod drugih oblika zdravstvenih ponašanja. Optimističnije žene češće si same pregledavaju grudi (Friedman, Nelson, Webb, Hoffman i Baer, 1994), a kada su trudne, češće vježbaju, što je povezano s dužom gestacijskom dobi i većom tjelesnom težinom novorođenčadi (Lobel i sur., 2000). Kod HIV seronegativnih muškaraca optimizam je povezan $\mathrm{s}$ manjim brojem nepoznatih seksualnih partnera (Taylor i sur., 1992), dok je kod liječenih alkoholičara pesimizam povezan $\mathrm{s}$ češćim napuštanjem programa liječenja i ponovnim konzumiranjem alkohola (Strack, Carver i Blaney, 1987). Također, optimizam je povezan s bržim traženjem liječničke pomoći kod simptoma raka dojke (Lauver i Tak, 1995), kao i s cijelim nizom drugih zdravstveno korisnih ponašanja (Lemola, Raikkonen, Gomez i Allemand, 2013; Taber i sur., 2015). Dakle, optimisti se češće nego pesimisti angažiraju u pozitivnim zdravstvenim ponašanjima. Scheier i Carver (1992) pretpostavljaju da se to događa zbog toga jer optimisti više nego pesimisti vjeruju da mogu postići željene ciljeve, pa s tim u skladu u njihovo postizanje ulažu veći napor. Zbog toga su optimisti uspješniji u usvajanju novih i promjeni već postojećih nepoželjnih oblika zdravstvenog ponašanja.

Međutim, postoje i rezultati istraživanja koji pokazuju da je optimizam povezan sa sklonošću potcjenjivanja vjerojatnosti za oboljevanje, odnosno s tendencijom da se sebi pripisuje manji zdravstveni rizik nego drugim osobama, što se najčešće naziva nerealističnim optimizmom. Npr. Hoorens i Buunk (1993) su pokazali da je 
optimizam povezan s manjom percipiranom vjerojatnošću obolijevanja od srčanih bolesti te s manjom vjerojatnošću za samoubojstvo, AIDS i alkoholizam. Optimisti smatraju da će se razboljeti od manje opasnih bolesti i da će njihove posljedice biti blaže (Hevey i French, 2012). Također, podcjenjuju vjerojatnost javljanja povećanog krvnog tlaka kada se kao referentna mjera koriste obiteljska i osobna povijest hipertenzije, a $\mathrm{u}$ istom je istraživanju optimizam bio značajno negativno povezan $\mathrm{s}$ 24 od 52 ispitivane bolesti, što govori da kod optimista postoji generalizirana tendencija smanjene percipirane vjerojatnosti obolijevanja (O'Brien, VanEgeren i Mumby, 1995). Budući da je percipirana sklonost određenoj bolesti važan prediktor preventivnih zdravstvenih ponašanja, može se pretpostaviti da u nekim uvjetima optimizam dovodi do njihove snižene razine. Rezultati nekih istraživanja to i potvrđuju. Optimisti poduzimaju manje preventivnih zdravstvenih ponašanja vezanih uz povećani krvni tlak i obolijevanje od zaraznih bolesti (O'Brien i sur., 1995; Rudisill, 2013), a optimistični pušači smatraju da imaju manju vjerojatnost oboljevanja od raka pluća i srčanih bolesti nego što smatraju za prosječnog pušača iste dobi i spola (Hahn i Renner, 1998). Optimistička su očekivanja vjerojatno jedan od važnih faktora koji objašnjava zbog čega ljudi nastavljaju s negativnim zdravstvenim ponašanjima usprkos tome što znaju kakve su njihove posljedice.

Zbog toga što optimizam može imati različite efekte na zdravstvena ponašanja, važno je znati u kojim uvjetima on dovodi do pozitivnih, a u kojima do negativnih posljedica. Schwarzer (1999) smatra da treba razlikovati nerealistični ili defanzivni optimizam i funkcionalni optimizam. Defanzivni je optimizam kognitivna pristranost koja predstavlja negiranje realne opasnosti, a funkcionalni optimizam vjerovanje da su naši resursi i sposobnosti suočavanja adekvatni za buduće izazove i negative događaje. Primjer čestice koja se odnosi na defanzivni optimizam je "U usporedbi s drugim osobama istog spola i dobi ja sam manje sklon raku pluća.", dok se funkcionalni optimizam mjeri česticama kao "Siguran sam da se mogu suzdržati od pušenja, čak i ako me prijatelj ponudi cigaretom.". Ove dvije vrste optimizma imaju različite posljedice na preventivna zdravstvena ponašanja. Defanzivni optimizam, zasnovan na nerealnoj percepciji nepostojanja zdravstvenog rizika, otežava donošenje odluke o poduzimanju nužnih preventivnih koraka. S druge strane, funkcionalni optimizam, zasnovan na optimističkoj procjeni vlastitih resursa, predstavlja prvi važan preduvjet za započinjanje preventivnih ponašanja. Uz razlikovanje defanzivnog i funkcionalnog optimizma čini se da i neki drugi faktori određuju efekte optimizma na zdravstvena ponašanja. Naime, istraživanja pokazuju da je nerealistični optimizam pozitivno povezan s procjenom mogućnosti kontrole nad budućim događajem (Hoorens i Buunk, 1993), da djelomično ovisi i o stvarnoj vjerojatnosti događaja (Weinstein i Lyon, 1999), kao i o karakteristikama bolesti (de Ridder, Schreurs i Bensing, 2000). Npr. kod kontrolabilnih bolesti, čiji ishod jako ovisi o pridržavanju pripisanoga zdravstvenog tretmana, pretjerani optimizam može biti ugrožavajući, međutim, kod nekontrolabilnih bolesti visok stupanj optimizma može biti nužan za suočavanje s različitim stresorima vezanim uz oboljenje. Iako je nužno bolje poznavanje efekata nerealističnog optimizma, posebno u različitim 
fazama iniciranja preventivnih zdravstvenih ponašanja, treba napomenuti da je nerealistični optimizam vrlo snažan fenomen koji je teško eliminirati i koji preko svojih učinaka na zdravstvena ponašanja može imati vrlo značajne zdravstvene posljedice.

\section{Optimizam, pesimizam i suočavanje sa stresom}

Efekti optimizma i pesimizma na zdravstvene ishode mogu biti posredovani i načinima suočavanja (Avvenuti, Baiardini i Giardini, 2016). Tome u prilog idu i rezultati istraživanja koji pokazuju da se optimisti i pesimisti koriste različitim načinima suočavanja. Kada se radi o situacijski specifičnim strategijama suočavanjima, Scheier, Weintraub i Carver (1986) su našli da je optimizam pozitivno povezan s problemu usmjerenim suočavanjem, pogotovo kod onih ispitanika koji su stresni događaj percipirali kontrolabilnim. Optimizam je također pozitivno povezan s pozitivnom reinterpretacijom događaja i traženjem socijalne podrške, te kod nekontrolabilnih stresnih situacija i s pokušajima prihvaćanja realnosti situacije. Pesimizam je povezan uglavnom sa suočavanjem izbjegavanjem, posebno $\mathrm{s}$ njegovim komponentama nazvanim negiranje i distanciranje od problema, kao i s nekim komponentama emocijama usmjernog suočavanja, posebno ventiliranjem emocija. Kada se radi o dispozicijskim stilovima suočavanja, istraživanja pokazuju slične rezultate. Optimizam je uglavnom povezan s problemu usmjerenim stilovima suočavanja, posebno aktivnim suočavanjem i planiranjem, dok je pesimizam povezan s dispozicijskom tendencijom izbjegavanja ciljeva povezanim sa stresom. Također, optimisti češće prihvaćaju realnost stresnog događaja, dok pesimisti češće koriste negiranje te alkohol i tablete za smirenje koje im olakšavaju izbjegavanje stresnog događaja (Carver, Scheier i Weintraub, 1989; Wray, Dvorak, Hsia, Arens i Schweinle, 2013). Rezultati ostalih istraživanja izvršenih na zdravim ispitanicima (Fontaine, Manstead i Wagner, 1993), ispitanicima s rizikom za oboljevanje (Fowler i Geers, 2015; Taylor i sur., 1992) i bolesnicima (Carver i sur., 1993; Epping-Jordan i sur., 1999; Miller, Manne, Taylor, Keates i Dougherty, 1996; Scheier i sur., 1989) uglavnom potvrđuju spomenute odnose optimizma i pesimizma sa suočavanjem. Tako su npr. Taylor i suradnici (1992) na uzorku muškaraca s rizikom za dobivanje AIDS-a našli da optimisti pri suočavanju s neželjenim mislima vezanim uz mogućnost dobivanja AIDS-a češće nastoje održati pozitivne stavove, dok se kod pesimista više javlja fatalizam, samookrivljavanje i izbjegavanje. Kod pacijenata kojima je ugrađena srčana premosnica nađeno je da su optimisti preoperativno manje usmjereni na negativne aspekte svojih emocionalnih doživljaja, a više su nego pesimisti usmjereni na planiranje i postavljanje ciljeva tijekom svoga budućeg oporavka (Scheier i sur., 1989). Pesimisti su manje vezani uz svoje postoperativne ciljeve, a ta je tendencija još više naglašena nakon operacije. Oni tada aktivno pokušavaju blokirati misli o negativnim aspektima svog iskustva, kao što su npr. simptomi, dok optimisti nastoje dobiti što je moguće više informacija o kasnijem tretmanu. 
Navedeni rezultati jasno pokazuju da i u stresnim situacijama optimisti ostaju vezani uz svoje životne ciljeve, za razliku od pesimista, koji nastoje izbjeći situacije vezane uz stres. Scheier i suradnici (1989) smatraju da je ovakav uzorak suočavanja pesimista posljedica toga što su negativna očekivanja poticaj za fizičko izbjegavanje konteksta u kojem se stres događa, a kada to nije moguće, zamjenjuje ga tendencija mentalnog izbjegavanja. Nasuprot njima, optimisti u stresnim situacijama nastoje učiniti što je najbolje moguće, pokušavaju situaciju sagledati u boljem svjetlu i nešto naučiti iz tog iskustva (Feng, Li i Chen, 2015). Međutim, optimizam nema samo proaktivnu ulogu u suočavanju sa stresnim situacijama, nego i akomodacijsku, koja ponekad također može biti vrlo važna (Carver i Scheier, 2014). Kao što se iz prethodno navedenih rezultata vidi, optimizam je povezan is prihvaćanjem realnosti stresnih situacija. Mnogi stresovi uključuju prijetnje i gubitke, pri čemu ne možemo učiniti ništa nego se prilagoditi novoj situaciji. Kao što ulažu napor usmjeren na promjenu u onim situacijama u kojima je to moguće, optimisti isto tako prihvaćaju stvari kada se one ne mogu promijeniti i bolje se prilagođavaju novom stanju (Carver i Scheier, 2014).

Iako se optimisti i pesimisti različito suočavaju sa stresnim situacijama, važno je pitanje u kojoj mjeri suočavanja posreduju efekte ovih dviju dimenzija na zdravstvene ishode. Istraživanja ovog problema nisu uvijek došla do jednoznačnih rezultata. U istraživanju Scheiera i suradnika (1989) efekti optimizma na intraoperativne komplikacije, liječničke procjene tjelesnog oporavka i normalizaciju svakodnevnih aktivnosti nisu bile posredovane strategijama suočavanja. Jedino su efekti optimizma na procjenu kvalitete života bili posredovani strategijom suočavanja koja je uključivala razmišljanje o negativnom afektu. Na uzorku ispitanika oboljelih od raka optimizam je povezan s psihološkom prilagodbom, ali njegov efekt nije posredovan strategijama suočavanja (Miller i sur., 1996). Isto je i s njegovim efektima na subjektivne tjelesne simptome kod zdravih ispitanika (Bretherton i McLean, 2015) i na doživljaj stresa kod članova spasilačkih ekipa (Dougall, Hyman, Hayward, McFeeley i Baum, 2001) te ratnih zarobljenika koji su doživjeli traumatsko iskustvo (Segovia, Moore, Linnville i Hoyt, 2015).

Češći su rezultati koji govore o značajnoj posredničkoj ulozi stilova suočavanja. Tako npr. Stanton i Snider (1993) nalaze da suočavanje izbjegavanjem posreduje efekte optimizma na doživljaj stresa kod žena koje očekuju rezultate biopsije, a Carver i suradnici (1993) navode da su kod žena operiranih od raka dojke efekti optimizma na doživljaj stresa i prije operacije i nakon nje posredovani trima strategijama suočavanja - prihvaćanjem, niskim negiranjem i ponašajnim izbjegavanjem. Rezultati dobiveni na sličnom uzorku ispitanica pokazuju da se pesimistične žene više koriste emocijama usmjerenim suočavanjima, posebno samokritičnošću i socijalnim povlačenjem, te da je korištenje tih strategija povezano $\mathrm{s}$ većim doživljajem stresa kod dijagnoze i šest mjeseci kasnije (Epping-Jordan i sur., 1999). Ispitujući fizičku rehabilitaciju i psihološku prilagodbu pacijenata kojima je ugrađena srčana premosnica, Ben-Zur i suradnici (2000) nalaze da emocijama 
usmjereno suočavanje kod pesimista postoperativno dovodi do većeg doživljaja stresa i sporije rehabilitacije, dok kod žena sličnoga zdravstvenog statusa strategije prihvaćanja i neizbjegavanja posreduju efekte optimizma na pozitivno raspoloženje (King, Rowe, Kimble i Zerwic, 1998).

Iz navedenih se rezultata može vidjeti da efekti optimizma i pesimizma na ishodne varijable mogu biti posredovani načinima suočavanja. Problemu usmjereno suočavanje i prihvaćanje najčešće posreduju efekte optimizma, a suočavanje izbjegavanjem i emocijama usmjereno suočavanje efekte pesimizma. Međutim, za sada još uvijek nedostaju istraživanja u kojima bi bile uključene obje dimenzije, i optimizam i pesimizam, te u kojima bi se koristili i objektivni indikatori zdravstvenih ishoda. Naime, dosadašnja su istraživanja pokazala da suočavanja posreduju efekte optimizma i pesimizma uglavnom na ishodne varijable koje se odnose na psihološka stanja (intenzitet doživljanog stresa, raspoloženje i sl.) zdravih ispitanika i bolesnika. Iako ta stanja sama po sebi mogu biti važna za zdravstveno stanje ispitanika, dosadašnja nam istraživanja malo govore o tome posreduju li suočavanja efekte optimizma i pesimizma i na objektivne zdravstvene indikatore.

\section{Problemi u istraživanjima odnosa optimizma i pesimizma sa zdravstvenim ishodima}

Na kraju, potrebno je spomenuti još neke nedovoljno razjašnjene probleme koji se pojavljuju u istraživanjima odnosa optimizma i pesimizma sa zdravstvenim ishodima, a odgovore na njih trebala bi dati buduća istraživanja.

Prvi je takav problem razlikovanje između situacijski specifičnog i dispozicijskog optimizma. Naime, očekivanja budućih pozitivnih i negativnih događaja mogu varirati od vrlo specifičnih (npr. "Mogu li za mjesec dana smršavjeti tri kilograma?") preko umjereno općenitih (npr. "Hoću li se oporaviti nakon dijagnoze karcinoma dojke?") do vrlo općenitih (npr. "Jesam li uspješan u gotovo svemu što pokušam učiniti?"). Najveći broj teorija zasnovanih na konceptu očekivanja podrazumijeva da se najbolje predviđanje ishoda ostvaruje onda kada se razina specifičnosti-općenitosti očekivanja poklapa $\mathrm{s}$ razinom ishoda. U istraživanjima zdravstvenih posljedica optimizma i pesimizma koriste se vrlo različite razine specifičnosti-općenitosti ovih dviju dimenzija, pri čemu se one ponekad ne poklapaju s razinom specifičnosti-općenitosti ispitivanih zdravstvenih ishoda. Najčešće se koriste mjere dispozicijskog optimizma, koje zahvaćaju vrlo opća, generalizirana očekivanja. Međutim, te mjere nisu podjednako prikladne za sve vrste ishoda. Dispozicijski je optimizam najprikladniji za ishode koji su po svojoj prirodi općeniti ili višestruko determinirani, koji se sporo razvijaju tijekom dužega vremenskog perioda, te za one s kojima osoba nema prethodnih iskustava. Međutim, kada želimo predvidjeti neki pojedinačan ishod, tada nam korisnija mogu biti specifična očekivanja. Npr. ispitujući oporavak nakon operacije ugradnje srčanih 
premosnica, Scheier i suradnici (1989) nalaze da specifična očekivanja bolje predviđaju normalizaciju svakodnevnih aktivnosti nego dispozicijski optimizam. Peterson (2000) pretpostavlja da je dispozicijski optimizam biološka tendencija kojoj kultura daje socijalno prihvatljiv sadržaj, dok su specifična očekivanja posljedica jedinstvene povijesti učenja svakog pojedinca. Dispozicijski optimizam dovodi do željenih ciljeva jer izaziva opće stanje energičnosti i odlučnosti, a specifična očekivanja jer pojedinca predisponiraju na specifične aktivnosti koje su adaptivne u konkretnim situacijama.

Ono što je također bitno za istraživanja zdravstvenih posljedica optimizma i pesimizma je mogućnost da njihove različite razine specifičnosti-općenitosti ostvaruju efekte na ishodne varijable različitim mehanizmima. Tako npr. neki autori navode da bi se tijek teških oboljenja, kao što su AIDS i karcinom, mogao bolje predvidjeti na osnovi dispozicijskog optimizma, koji ima snažniji efekt na imunološko funkcioniranje i raspoloženja, dok bi sama pojava oboljenja i vjerojatnost traumatskih ozljeda mogle biti više pod utjecajem situcijski specifičnih očekivanja, koja djeluju na ponašanje i izbor životnog stila (Peterson, 2000). Dosadašnja su istraživanja vrlo rijetko uključivala više mjera optimizma, a i onda kada jesu, autore je više zanimala povezanost među njima nego mogućnost da one ostvaruju različite povezanosti s ishodnim varijablama.

Drugi je važan problem tretiranje optimizma i pesimizma kao jedne bipolarne umjesto kao dvije posebne dimenzije (Carver, Scheier i Segerstrom, 2010). Usprkos sve većoj evidenciji da se najvjerojatnije radi o dvije dimenzije, u najvećem se broju istraživanja optimizam i pesimizam još uvijek mjere kao jedna bipolarna dimenzija. Različita shvaćanja dimenzionalnosti optimizma i pesimizma mogu imati važne posljedice i za istraživanja zdravstvenih ishoda. Naime, mali broj dosadašnjih istraživanja u kojima su ispitivani nezavisni efekti obiju dimenzija pokazuje da ove dvije dimenzije predviđaju djelomično različite zdravstvene ishode. Sumirajući rezultate tih istraživanja Mahler i suradnici (2000) navode da postoji tendencija da je optimizam više povezan s mjerama subjektivnih tjelesnih simptoma, a pesimizam s mjerama tjelesnog zdravlja. Također, postoji mogućnost da je prediktivna snaga optimizma i pesimizma različita kod različitih vrsta stresora, odnosno da su obje dimenzije važne za zdravstvene ishode, ali u različitim vremenskim okvirima. U istraživanjima u kojima je nađeno da se zdravstveni ishodi bolje mogu predvidjeti na osnovi pesmizma ishodne su varijable mjerene više mjeseci nakon primjene LOT upitnika. Nasuprot tome, u onim istraživanjima u kojima je optimizam bio bolji prediktor ishodi su mjereni retrospektivno ili nakon nekoliko tjedana. Istraživanje Cohena i suradnika (1999) također pokazuje da optimizam ima zaštitni efekt na imunološko funkcioniranje kod djelovanja akutnih stresora, međutim, kod kroničnih stresora značajnija je uloga niskog pesimizma. Dakle, navedena istraživanja upućuju na mogućnost da je optimizam bolji prediktor relativno akutnih ishoda, dok je pesimizam važniji kod predviđanja dugotrajnijih ishoda. 
Treći važan problem vezan uz istraživanje zdravstvenih posljedica optimizma vezan je uz njegovu povezanost s realnošću. Kao što je već navedeno, prevelik ili nerealističan optimizam može imati negativne posljedice na zdravstveno ponašanje, a preko njih i na zdravstvene ishode. Negativne posljedice nerealističnog optimizma nisu nađene samo kod zdravstvenih ponašanja. Istraživanja pokazuju da su ispitanici koji svoje mentalno zdravlje procjenjuju pretjerano optimistično manje otporni na stres nego oni koji su realniji u procjeni svog mentalnog zdravlja (Shedler, Mayman i Manis, 1993), a slični se nalazi dobivaju i kod onih ispitanika koji potiskuju negativne emocije (Gross i Levenson, 1997). Osobe koje pretjerano optimistički procjenjuju svoja emocionalna stanja negirajući svoje negativne emocije pokazuju značajno snažnije fiziološke reakcije na stres od osoba koje su realistične u pogledu svojih negativnih emocija. Osim toga, konstantno nastojanje za ostvarivanjem ciljeva ili održavanjem kontrole nad događajima, posebno kada to nije praćeno odgovarajućim resursima, može imati i svoju cijenu u obliku iscrpljenosti, demoralizacije i bolesti (Peterson, 2000). Moguća je i obrnuta situacija, tj. da preveliki optimizam dovede do neaktivnosti, odnosno do očekivanja da će se željeni cilj i bez našeg kontinuiranog nastojanja već nekako ostvariti. Također, znak mentalnog zdravlja je adekvatan kontakt s realnošću, a ne preveliko odstupanje, pa bilo ono i u pozitivnom smjeru. Zbog toga se u novije vrijeme javljaju koncepcije optimizma koje uzimaju u obzir i navedene opasnosti prevelikog optimizma. One se zasnivaju na pretpostavci o korisnosti umjerene razine optimizma, ili kako navodi Baumeister (1988), optimalne razine pozitivne iluzije koja ljudima omogućava da se vide boljima nego što stvarno jesu, ali koja uobičajeno ne dovodi do ponašanja koja bi se temeljila na netočnim vjerovanjima. Jedna je od tih koncepcija i koncepcija o realističnom optimizmu (Schneider, 2001), odnosno očekivanju budućih pozitivnih događaja, ali uzimajući u obzir i ograničenja fizičkog i socijalnog svijeta. Naredna bi istraživanja trebala ispitati dovodi li realistični optimizam također do pozitivnih ishoda koji su karakteristični za optimizam, ali uz izbjegavanje negativnih posljedica do kojih ponekad dovodi preveliki optimizam.

\section{Literatura}

Affleck, G., Tennen, H. i Gershman, K. (1985). Cognitive adaptations to a high risk infant: The search for meaning, mastery, and protection from future harm. American Journal of Mental Deficiency, 89, 653-656.

Ammirati, R. J., Lamis, D. A., Campos, P. E. i Farber, E. W. (2015). Optimism, well-being, and perceived stigma in individuals living with HIV. AIDS Care, 27, 926-933.

Andersson, G. (1996). The benefits of optimism: A meta-analytic review of the LifeOrientation Test. Personality and Individual Differences, 21, 719-725.

Antoni, M. H. i Goodkin, K. (1988). Host moderator variables in the promotion of cervical neoplasia. I: Personality facets. Journal of Psychosomatic Research, 32, 327-338. 
Avvenuti, G., Baiardini, I. i Giardini, A. (2016). Optimism's explicative role for chronic disease. Frontiers in Psychology. doi:https://doi.org/10.3389/fpsyg.2016.00295

Baumeister, R. F. (1988). The optimal margin of illusion. Journal of Social and Clinical Psychology, 8, 176-189.

Beck, A. T., Weissman, A., Lester, D. i Trexler, L. (1974). The measurement of pessimism: The Hopelessness Scale. Journal of Consulting and Clinical Psychology, 42, 861-865.

Ben-Zur, H., Rappaport, B., Ammar, R. i Uretzky, G. (2000). Coping strategies, life style changes, and pessimism after open-heart surgery. Health and Social Work, 25, 201-209.

Bleiker, E. M. A., van der Ploeg, H. M., Ader, H. J. i Hendriks, J. H. C. L. (1996). Personality factors and breast cancer development: A prospective longitudinal study. Journal of the National Cancer Institute, 88, 1478-1482.

Boehm, J. K., Chen, Y., Koga, H., Mathur, M. B., Vie, L. L. i Kubzansky, L. D. (2018). Is optimism associated with healthier cardiovascular-related behavior? Meta-analyses of 3 health behaviors. Circulation Research, 122, 1119-1134.

Bretherton, S. J. i McLean, L. A. (2015). Interrelations of stress, optimism and control in older people's psychological adjustment. Australasian Journal of Aging, 34, 103-108.

Burke, K. L., Joyner, A. B., Czech, D. R. i Wilson, M. J. (2000). An investigation of concurrent validity between two optimism/pessimism questionnaires: The Life Orientation Test-Revised and the Optimism/Pessimism Scale. Current Psychology, 19, 129-136.

Byrnes, D. M., Antoni, M. H., Goodkin, K., Efantis-Potter, J., Asthana, D., Simon, T., Munajj, J., Ironson, G. i Fletcher, M. A. (1998). Stressful events, pessimism, natural killer cell cytotoxicity, and cytotoxic/suppressor T cells in HIV+ black women at risk for cervical cancer. Psychosomatic Medicine, 60, 714-722.

Carver, C. S. i Scheier, M. F. (2014). Dispositional optimism. Trends in Cognitive Sciences, 18, 293-299.

Carver, C. S., Scheier, M. F. i Segerstrom, S. C. (2010). Optimism. Clinical Psychology Review, 30, 879-889.

Carver, C. S., Scheier, M. F. i Weintraub, J. K. (1989). Assessing coping strategies: A theoretically based approach. Journal of Personality and Social Psychology, 56, $267-$ 283.

Carver, C. S., Pozo, C., Harris, S. D., Noriega, V., Scheier, M. F., Robinson, D. S., Ketcham, A. S., Moffat, F. L. i Clark, K. C. (1993). How coping mediates the effect of optimism on distress: A study of women with early stage breast cancer. Journal of Personality and Social Psychology, 65, 375-390.

Chida, Y. i Steptoe, A. (2008). Positive psychological well-being and mortality: A quantitative review of prospective observational studies. Psychosomatic Medicine, 70, 741-756. 
Cohen, F., Kearney, K. A., Zegans, L. S., Kemeny, M. E., Neuhaus, J. M. i Stites, D. P. (1999). Differential immune system changes with acute and persistent stress for optimists vs pessimists. Brain, Behavior and Immunity, 13, 155-174.

Cruess, S., Antoni, M., Kilbourn, K., Ironson, G., Klimas, N., Fletcher, M. A., Baum, A. i Schneiderman, N. (2000). Optimism, distress, and immunologic status in HIV-infected gay men following Hurricane Andrew. International Journal of Behavioral Medicine, 7, 160-182.

Danner, D. D., Snowdon, D. A. i Friesen, W. V. (2001). Positive emotions in early life and longevity: Findings from the nun study. Journal of Personality and Social Psychology, 80, 804-813.

Dember, W. N., Martin, S. H., Hummer, M. K., Howe, S. R. i Melton, R. S. (1989). The measurement of optimism and pessimism. Current Psychology: Research and Reviews, $8,102-119$.

de Ridder, D., Schreurs, K. i Bensing, J. (2000). The relative benefits of being optimistic: Optimism as a coping resource in multiple sclerosis and Parkinson's disease. British Journal of Health Psychology, 5, 141-155.

Dougall, A. L., Hyman, K. B., Hayward, M. C., McFeeley, S. i Baum, A. (2001). Optimism and traumatic stress: The importance of social support and coping. Journal of Applied Social Psychology, 31, 223-245.

DuBois, C. M., Lopez, O. V., Beale, E. E., Healy, B. C., Boehm, J. K. i Huffman, J. C. (2015). Relationships between positive psychological constructs and health outcomes in patients with cardiovascular disease: A systematic review. International Journal of Cardiology, $195,265-280$.

Epping-Jordan, J. E., Compas, B. E., Osowiecki, D. M., Oppedisano, G., Gerhardt, C., Primo, K. i Krag, D. N. (1999). Psychological adjustment in breast cancer: Processes of emotional distress. Health Psychology, 18, 315-326.

Feng, J., Li, S. i Chen, H. (2015). Impacts of stress, self-efficacy, and optimism on suicide ideation among rehabilitation patients with acute pesticide poisoning. PLOS ONE, 10. doi:10.1371/journal.pone.0118011

Ferrer, R. A., Klein, W. M. P., Zajac, L. E., Sutton-Tyrrell, K., Muldoon, M. F. i Kamarck, T. W. (2012). Unrealistic optimism is associated with subclinical atherosclerosis. Health Psychology, 31, 815-820.

Fibel, B. i Hale, W. D. (1978). The Generalized Expectancy for Success Scale: A new measure. Journal of Consulting and Clinical Psychology, 46, 924-931.

Fontaine, K. R., Manstead, A. S. R. i Wagner, H. (1993). Optimism, perceived control over stress, and coping. European Journal of Personality, 7, 267-281.

Fowler, S. L. i Geers, A. L. (2015). Dispositional and comparative optimism interact to predict avoidance of a looming health threat. Psychology and Health, 4, 456-474. 
Friedman, H. S., Tucker, J. S., Tomlinson-Keasey, C., Schwartz, J., Wingard, D. i Criqui, M. (1993). Does childhood personality predict longevity? Journal of Personality and Social Psychology, 65, 176-185.

Friedman, L. C., Nelson, D. V., Webb, J. A., Hoffman, L. P. i Baer, P. E. (1994). Dispositional optimism, self-efficacy, and health beliefs as predictors of breast self-examination. American Journal of Preventive Medicine, 10, 130-135.

Gallagher, M. W., Lopez, S. J. i Pressman, S. D. (2013). Optimism is universal: Exploring the presence and benefits of optimism in a representative sample of the world. Journal of Personality, 81, 429-440.

Glaesmer, H., Rief, W., Martin, A., Mewes, R., Brahler, E., Zenger, M. i Hinz, A. (2012). Psychometric properties and population-based norms of the Life orientation Test Revised (LOT-R). British Journal of Health Psychology, 17, 432-445.

Gross, J. J. i Levenson, R. W. (1997). Hiding feelings: The acute effects of inhibiting negative and positive emotion. Journal of Abnormal Psychology, 106, 95-103.

Hahn, A. i Renner, B. (1998). Perception of health risk: How smoker status affects defensive optimism. Anxiety, Stress and Coping, 11, 93-112.

Helgeson, V. S. i Fritz, H. L. (1999). Cognitive adaptation as a predictor of new coronary events after precutaneous transluminal coronary angioplasty. Psychosomatic Medicine, $61,488-495$.

Hevey, D. i French, D. P. (2012). Comparative optimism for severity of negative health outcomes. Psychology, Health and Medicine, 17, 417-426.

Hevey, D., McGee, H. M. i Horgan, J. H. (2014). Comparative optimism among patients with coronary heart disease (CHD) is associated with fewer adverse clinical events 12 months later. Journal of Behavioral Medicine, 37, 300-307.

Hodges, K. i Winstanley, S. (2012). Effects of optimism, social support, fighting spirit, cancer worry and internal health locus of control on positive affect in cancer survivors: A path analysis. Stress and Health, 28, 408-415.

Hoorens, V. i Buunk, B. P. (1993). Social comparison of health risk: Locus of control, the person-positivity bias, and unrealistic optimism. Journal of Applied Social Psychology, 23, 291-302.

Hummer, M. K., Dember, W. N., Melton, R. S. i Schefft, B. K. (1992). On the partial independence of optimism and pessimism. Current Psychology, 11, 37-50.

King, K. B., Rowe, M. A., Kimble, L. P. i Zerwic, J. J. (1998). Optimism, coping, and longterm recovery from coronary artery surgery in women. Research in Nursing and Health, $21,15-26$.

Lauver, D. i Tak, Y. (1995). Optimism and coping with a breast cancer symptom. Nursing Research, 44, 202-207.

Lemola, S., Raikkonen, K., Gomez, G. i Allemand, M. (2013). Optimism and self-esteem are releted to sleep: Results from large community-based sample. International Journal of Behavioral Medicine, 20, 567-571. 
Lewis, L. M. i Dember, W. N. (1995). Can experimentally induced mood affect optimism and pessimism scores? Current Psychology, 14, 29-41.

Lobel, M., DeVincent, C. J., Kaminer, A. i Meyer, B. A. (2000). The impact of prenatal maternal stress and optimistic disposition on birth outcomes in medically high-risk women. Health Psychology, 19, 544-553.

Lyons, A. i Chamberlain, K. (1994). The effects of minor events, optimism and self-esteem on health. British Journal of Clinical Psychology, 33, 559-570.

Mahler, H. I. M., Kulik, J. A., Hudson, J., Bradford, B., Weinrich, M., Young, M. A. i Tucker, K. (2000). Optimism, pessimism and recovery from coronary bypass surgery: Prediction of affect, pain and functional status. Psychology, Health and Medicine, 5, 347-358.

Matlin, M. i Stang, D. (1978). The Pollyanna principle: Selectivity in language, memory and thought. Cambridge, MA: Schenkman.

Miller, D. L., Manne, S. L., Taylor, K., Keates, J. i Dougherty, J. (1996). Psychological distress and well-being in advanced cancer: The effects of optimism and coping. Journal of Clinical Psychology in Medical Settings, 3, 115-130.

Morris, W. N. (1989). Mood: The frame of mind. New York: Springer-Verlag.

Mroczek, D. K., Spiro, A., Aldwin, C. M., Ozer, D. J. i Bosse, R. (1996). Construct validation of the optimism and pessimism in older men: Findings from the normative aging study. Health Psychology, 12, 406-409.

Nes, L. S., Segerstrom, S. C. i Sephton, S. E. (2005). Engagement and arousal: Optimism's effects during a brief stressor. Personality and Social Psychology Bulletin, 31, 111-120.

Newman, M. G. i Stone, A. A. (1996). Does humor moderate the effects of experimentallyinduced stress? Annals of Behavioral Medicine, 18, 101-109.

O'Brien, W. H., VanEgeren, L. i Mumby, P. (1995). Prediciting health behaviors using measures of optimism and perceived risk. Health Values, 19, 21-28.

Peterson, C. (2000). The future of optimism. American Psychologist, 55, 44-55.

Peterson, C., Seligman, M. E. P, Yurko, K. H., Martin, L. R. i Friedman, H. S. (1998). Catastrophizing and untimely death. Psychological Science, 9, 127-130.

Rasmussen, H. N., Scheier, M. F. i Greenhouse, J. B. (2009). Optimism and physical health. Annals of Behavioral Medicine, 37, 239-256.

Reed, G. M., Kemeny, M. E., Taylor, S. E. i Visscher, B. R. (1999). Negative HIV-specific expectancies and AIDS-related bereavement as predictors of symptom onset in asymptomatic HIV-positive gay men. Health Psychology, 18, 354-363.

Reed, G. M., Kemeny, M. E., Taylor, S. E., Wang, H. Y. J. i Visscher, B. R. (1994). "Realistic acceptance" as a predictor of decreased survival time in gay men with AIDS. Health Psychology, 13, 299-307.

Rini, C. K., Dunkel-Schetter, C., Wadhwa, P. D. i Sandman, C. A. (1999). Psychological adaptation and birth outcomes: The role of personal resources, stress, and sociocultural context in pregnancy. Health Psychology, 18, 333-345. 
Rotton, J. (1992). Trait humor and longevity: Do comics have the last laugh? Health Psychology, 11, 262-266.

Rudisill, C. (2013). How do we handle new health risks? Risk perception, optimism, and behaviors regarding the H1N1 virus. Journal of Risk Research, 16, 959-980.

Salovey, P., Detweiler, J. B., Steward, W. T. i Rothman, A. J. (2000). Emotional states and physical health. American Psychologist, 55, 110-121.

Scheier, M. E. i Carver, C. S. (1985). Optimism, coping, and health: Assessment and implications of generalized outcome expectancies. Health Psychology, 4, 219-247.

Scheier, M. F. i Carver, C. S. (1987). Dispositional optimism and physical well-being: The influence of generalized outcome expectancies on health. Journal of Personality, 55, 169-210.

Scheier, M. F. i Carver, C. S. (1992). Effects of optimism on physical well-being: Theoretical overview and empirical update. Cognitive Therapy and Research, 16, 201-228.

Scheier, M. R., Carver, C. S. i Bridges, M. W. (1994). Distinguishing optimism from neuroticism (and trait anxiety, self-mastery, and self-esteem): A reevaluation of the Life Orientation Test. Journal of Personality and Social Psychology, 67, 1063-1078.

Scheier, M. F., Matthews, K. A., Owens, J. F., Magovern, G. J., Lefebvre, R. C., Abbott, R. A. i Carver, C. S. (1989). Dispositional optimism and recovery from coronary artery bypass surgery: The beneficial effects on physical and psychological well-being. Journal of Personality and Social Psychology, 57, 1024-1040.

Scheier, M. F., Matthews, K. A., Owens, J. F., Schulz, R., Bridges, M. W., Magovern, G. J. i Carver, C. S. (1999). Optimism and rehospitalization after coronary artery bypass graft surgery. Archives of Internal Medicine, 159, 829-835.

Scheier, M. F., Weintraub, J. K. i Carver, C. S. (1986). Coping with stress: Divergent strategies of optimists and pessimists. Journal of Personality and Social Psychology, 54, 1257-1264.

Schneider, S. L. (2001). In search of realistic optimism: Meaning, knowledge, and warm fuzziness. American Psychologist, 53, 250-263.

Schulz, R., Bookwala, J., Knapp, J. E., Scheier, M. F. i Williamson, G. M. (1996). Pessimism, age, and cancer mortality. Psychology and Aging, 11, 304-309.

Schutte, N. S., Palanisamy, S. K. A. i McFarlane, J. R. (2016). The relationship between positive psychological characteristics and longer telomeres. Psychology and Health, 12, 1466-1480.

Schwarzer, R. (1999). Self-regulatory processes in the adoption and maintenance of health behaviors: The role of optimism, goal, and threats. Journal of Health Psychology, 4, 115-127.

Segerstrom, S. C. (2005). Optimism and immunity: Do positive thoughts always lead to positive effects? Brain, Behavior, and Immunity, 19, 195-200. 
Segerstrom, S. C. (2006). How does optimism suppress immunity? Evaluation of three affective pathways. Health Psychology, 25, 653-657.

Segerstrom, S. C., Taylor, S. E., Kemeny, M. E. i Fahey, J. L. (1998). Optimism is associated with mood, coping and immune change in response to stress. Journal of Personality and Social Psychology, 74, 1646-1655.

Segovia, F., Moore, J. L., Linnville, S. E. i Hoyt, R. E. (2015). Optimism predicts positive health in repatriated prisoners of war. Psychological Trauma: Theory, Research, Practice, and Policy, 7, 222-228.

Serlachius, A., Pulkki-Råback, L., Elovainio, M., Hintsanen, M., Mikkilä, V., Laitinen, T. T, Jokela, M., Rosenström, T., Josefsson, K., Juonala, K., Lehtimäki, T., Raitakari, O. i Keltikangas-Järvinen, L. (2015). Is dispositional optimism or dispositional pessimism predictive of ideal cardiovascular health? The young Finns study. Psychology and Health, 10, 1221-1239.

Shedler, J., Mayman, M. i Manis, M. (1993). The illusion of mental health. American Psychologist, 48, 1117-1131.

Shepperd, J. A., Maroto, J. J. i Pbert, L. A. (1996). Dispositional optimism as a predictor of health changes among cardiac patients. Journal of Research in Personality, 30, 517-534.

Sieber, W. J., Rodin, J., Larson, L., Ortega, S., Cummings, N., Levy, S., Whiteside, T. i Herberman, R. (1992). Modulation of human natural killer cell activity by exposure to uncontrollable stress. Brain, Behavior and Immunity, 6, 141-156.

Smith, T. W., Pope, M. K., Rhodewalt, F. i Poulton, J. L. (1989). Optimism, neuroticism, coping, and symptom reports: An alternative interpretation of the Life Orientation Test. Journal of Personality and Social Psychology, 56, 640-648.

Stanton, A. L. i Snider, P. R. (1993). Coping with a breast cancer diagnosis: A prospective study. Health Psychology, 12, 16-23.

Strack, S., Carver, C. S. i Blaney, P. H. (1987). Predicting successful completion of an aftercare program following treatment for alcoholism: The role of dispositional optimism. Journal of Personality and Social Psychology, 53, 579-584.

Strassle, C. G., McKee, E. A. i Plant, D. D. (1999). Optimism as an indicator of psychological health: Using psychological assessment wisely. Journal of Personality Assessment, 72, 191-200.

Taber, J. M., Klein, W. M. P., Ferrer, R. A., Lewis, K. L., Biesecker, L. G. i Biesecker, B. B. (2015). Dispositional optimism and perceived risk interact to predict intentions to learn genome sequencing results. Health Psychology, 34, 718-728.

Taylor, S. E. (1983). Adjustment to threatening events: A theory of cognitive adaptation. American Psychologist, 38, 1161-1173.

Taylor, S. E. i Brown, J. D. (1988). Illusion and well-being: A social-psychological perspective on mental health. Psychological Bulletin, 103, 193-210. 
Taylor, S. E., Kemeny, M. E., Aspinwall, L. G., Schneider, S. C., Rodriguez, R. i Herbert, M. (1992). Optimism, coping, psychological distress, and high-risk sexual behavior among men at risk for AIDS. Journal of Personality and Social Psychology, 63, 460-473.

Taylor, S. E., Kemeny, M. E., Bower, J. E., Gruenewald, T. L. i Reed, G. M. (2000). Psychological resources, positive illusions and, health. American Psychologist, 55, 99109.

Tomakovsky, J., Lumley, M. A., Markowitz, N. i Frank, C. (2001). Optimistic explanatory style and dispositional optimism in HIV-infected men. Journal of Psychosomatic Research, 51, 577-587.

Tucker, J. S. i Friedman, H. S. (1996). Emotion, personality and health. U: C. Magai i S. H. McFadden (Ur.), Handbook of emotion, adult development, and aging (str. 307-326). San Diego: Academic Press.

Weinstein, N. D. i Lyon, J. E. (1999). Mindset, optimistic bias about personal risk and healthprotective behaviour. British Journal of Health Psychology, 4, 289-300.

Williams, R. D., Riels, A. G. i Roper, K. A. (1990). Optimism and distractibility in cardiovascular reactivity. Psychological Record, 40, 451-457.

Wray, T. B., Dvorak, R. D., Hsia, J. F., Arens, A. M. i Schweinle, W. E. (2013). Optimism and pessimism as predictors of alcohol use trajectories in adolescence. Journal of Child and Adolescent Substance Abuse, 22, 58-68.

\title{
Optimism, Pessimism and Physical Health
}

\begin{abstract}
The effects of optimism and pessimism on physical health as well as potential mechanisms through which they exert their effects are reviewed in this article. The first part includes conceptual bases of optimism and pessimism, their measurement and measurement problems. Further, the most important empirical results about the effects of optimism and pessimism on mortality and other specific indices of physical health are shown. The relationships of optimism and pessimism with physical health indices in patients with HIV/AIDS are reviewed in more detail. Several potential mechanisms through which optimism and pessimism may affect physical health are described: cardiovascular reactivity, immune changes, health behaviors, stressful experience and coping with stress. Finally, some important theoretical and methodological problems of research on the relationship between optimism, pessimism and physical health are presented.
\end{abstract}

Keywords: optimism, pessimism, physical health, health behaviors 


\title{
Optimismo, pesimismo y salud física
}

\begin{abstract}
Resumen
En este artículo de revisión se han mostrado los efectos de optimismo y pesimismo sobre la salud física, tanto como posibles mecanismos a través de los cuales se realizan estos efectos. En la primera parte del trabajo se describe la base conceptual del optimismo y pesimismo, modos de su medición y problemas básicos que aparecen. Después se citan los hallazgos más importantes que tratan el efecto de optimismo y pesimismo sobre la mortalidad y otros indicadores específicos de salud física. Se han mostrado con más detalles las relaciones que el optimismo y pesimismo tienen con indicadores de salud física en las personas infectadas con el VIH y las que padecen de sida. Se ha descrito varios mecanismos a través de los cuales el optimismo y el pesimismo podrían ejercer un efecto sobre la salud física: reactividad cardiovascular, cambios inmunológicos, conductas de salud, sensación de estrés y afrontamiento al estrés. Al final se exponen algunos problemas teoréticos y metodológicos importantes que encontramos en las investigaciones de la relación entre el optimismo y pesimismo por una parte, y la salud física por otra.
\end{abstract}

Palabras clave: optimismo, pesimismo, salud física, conducta de salud

Primljeno: 10.09.2018. 